Отримано: 27 квітня 2020 р.

Прорецензовано: 30 квітня 2020 р.

Прийнято до друку: 30 квітня 2020 р.

e-mail: vika.ray1@gmail.com

DOI: $10.25264 / 2415-7384-2020-11-136-140$
Railianova V. E. Methods of foreign language teaching: psychological context. Науковi записки Національного університету «Острозька академія». Серія «Психологія» : науковий журнал. Острог : Вид-во НаУОА, червень 2020. № 11. С. 136-140.

\begin{abstract}
Viktoriia E. Railianova,
Phd in Linguistics, associate professor of the department of social and humanitarian disciplines, Dnipropetrovsk state university of internal affairs
\end{abstract}

\title{
METHODS OF FOREIGN LANGUAGE TEACHING: PSYCHOLOGICAL CONTEXT
}

The article demonstrates how the emergence and development of new methods of language teaching at school and university are related to new trends in linguistics, psychology and pedagogy. The problems that domestic and foreign methodologists face in the process of finding the most effective ways and methods of teaching are highlighted. In the article also were analyzed different points of view on understanding the psychological features of language acquisition, and in particular the principle of consciousness leading to the emergence of different teaching methods. The analysis of modern methods of teaching a foreign language, which pay attention to the psycholinguistic nature of the language, is made. Identified advantages and disadvantages.

Key words: approach, linguistics, speech, language, method, consciously-oriented, communicative, structural, grammatical, general psychology.

\author{
Райлянова Вікторія Едуардівна, \\ кандидат філологічних наук, \\ доиент кафедри соиіально-гуманітарних дисииллін \\ Дніпропетровського держаного університету внутрішніх справ
}

\section{МЕТОДИКИ ВИКЛАДАННЯ ІНОЗЕМНИХ МОВ: ПСИХОЛОГІЧНИЙ КОНТЕКСТ}

У статті демонструється як поява і розвиток нових методів навчання мови в школі та вузі пов'язані з новими тенденціями в лінгвістиці, психології та педагогіці. Висвечені проблеми, з якими стикаються вітчизняні та зарубіжні методисти в поцессе пошуку найбільш ефективних шляхів і методів навчання. Проаналізовано різні точки зору на розуміння психологічних особливостей оволодіння мовою, і зокрема принципу свідомості, щзо призводять до появи різноманітних методів навчання. Зроблено аналіз сучасних методів викладання іноземної мови, які звертають увагу на психолінгвістичну природу мови. Виявлені переваги та недоліки.

Ключові слова: лінгвістика, підхід, речь, мова, метод, когнитивний, комуникативний, структурний, граматичний, загальна пстхологія.

Problem statement. Each speech utterance, each act of generating or perceiving speech is multilaterally conditioned. Speech activity should be understood as the activity (behavior) of a person, to one extent or another, mediated by the signs of the language. L. Vygotsky formulated it more narrowly saying that speech activity should be understood as such activity in which a linguistic sign acts as a 'stimulus-means', i.e. such activity in which we form a speech utterance and use it to achieve some a predetermined goal [3]. Here we should say that it is one of the most difficult activities in all its parameters. Firstly, by its organization. To begin with, speech activity extremely rarely acts as an independent, complete act of activity: usually it is included as an integral part in activities of a higher order. For example, a typical speech utterance is an utterance that somehow regulates the behavior of another person. But this means that the activity can be considered completed only if such regulation is successful. In addition, components of speech activity are very different. These are typically mental actions for example, planning a speech utterance, and external actions such as activity of speech organs, and their mutual connection and interdependence is very difficult to determine precisely. Secondly, speech activity belongs to the type of the most complex and by the nature of the motives and goals presented in it. Indeed, it is not so simple to clearly formulate even such a seemingly elementary thing as the purpose of a speech utterance, that is, what is usually called a 'speech function' in the practice of scientific research. In works of N. Bekhtereva it is clearly shown that psychophysiological mechanism of speech, is characterized by a certain structure and can be represented as a kind of generative model, and this model is different from any other possible model of the language standard [2]. However, this model is not axiomatic, it is genetic.

Generating speech, we first have this incentive at the level of representation. Going down to the level of integration and combining with the experience gained in the process of perception at this level, this stimulus by association causes a reaction in the form of 'motor images', articulatory unity. Finally, at the projection level, all this takes on a real sound. All these levels are once and for all set in the neurological structure of the body. 
The motivational basis of the statement has a dual nature. As it has already been said before a speech utterance begins with the presence of a known motive - to convey something to another, to ask for something, or to clarify any thought. If this motive is absent, it is natural that the speech utterance cannot take place. On the other hand, the motivational basis of the utterance should consist in the initial concept, which later, through the means of a predictively constructed internal speech, turns into a scheme of an expanded speech utterance.

The methodology of teaching a foreign language as a science is based on modern knowledge of linguistics, psychology, psycholinguistics, neurolinguistics and the theory of teaching. Linguists have been working over creation of effective methodological systems, to contribute to the mastery of foreign languages, but such a system has not been created yet. Today, one can observe either the application of a slightly improved traditional technique, or experimentation with new methods, which so far do not give completely satisfactory results.

Analysis of latest researches and publications. In the methodology of foreign languages teaching there is a significant number of works on teaching vocabulary. Researchers focus on the psychological aspects of the assimilation and formation of foreign vocabulary. A significant number of works devoted to the lexical component of language competence $[5,11,14,17]$. As a result of these studies and developments, a communicative approach appeared, which is based on the priority of the formation of the lexical component. On the other hand, developments in the field of cognitive psychology have allowed linguists to formulate an approach called structural or grammatical. The structural approach is diametrically opposite to the communicative one. The grammatical approach gives the learner the opportunity to give the language a form, to form a structure on the basis of which lexical competencies will be formed. Active work in the field of cognitive psychology [12, 13, $15,18]$ allows us to consider this method as promising.

Purpose of the article. In short, purpose of the conducted work was: 1) a description of new developments of effective methods of teaching foreign languages; 2) a description of the results of implementation of such methods.

Materials and methods: theoretical analysis, comparison and generalization of scientific publications of the problems raised.

Main part. We all know that learning a foreign language is not an easy task. Here, skills are needed to memorize new words, study grammatical constructions and introduce existing linguistic knowledge. Nowadays, when the importance of interethnic communication is growing every year, the desire to master foreign languages as means of communication is developing on an ever wider scale. In order to organize the management of the pedagogical process as efficiently as possible, at the level of the requirements of modern science, it is necessary to know the nature of speech activity, forms of speech communication, ways of expressing speech content, psychological and psycholinguistic foundations of speech generation and perception, the relationship and interaction of all components of speech communication, the main pedagogical and methodological principles.

A foreign language, as a subject of instruction, involves the mastery of speech activity in a particular language, its linguistic material, as well as actions and operations with it. The process of speech activity is provided by speech skills and the ability to understand language by ear, speaking, reading and writing. These skills are primarily the content of teaching a foreign language. The means providing speech skills are language skills: phonetic, lexical, grammatical; their development is based on knowledge in the field of language aspects (phonetics, vocabulary, grammar). Therefore, linguistic knowledge and skills are included in the content of the training. Practical language knowledge is clothed in the form of dynamic stereotypes of linguistic signs of different levels (sounds, letters, syllables, words, phrases, structural patterns of sentences) stored in the long-term memory of a person with the ability of verbal communication. Therefore, the formation of language stereotypes and mechanisms for operating them is also included in the content of training.

A foreign language does not have its own content as opposed to such subjects as mathematics, physics, history, etc. It reflects the objective reality of the world around us. In diverse situations of verbal communication, all the wealth of the outside world is manifested. Using language as a means of cognition and communication, a person listens, speaks, reads, writes. The differentiations of the forms of communication are based on different criteria. By material means (sounds, letters) distinguish between oral and written speech, by conditions (interaction of communicants in space and time) - oral dialogue, oral monologue and written monologue. Information is obtained by listening and reading; transmitted - by speaking and writing. Listening and speaking are two sides of oral communication, naturally, they are characterized by the commonality of linguistic and verbal material, extra-linguistic means. Reading and writing are two aspects of written communication. They are based on writing. Extralinguistic means are less informative here than in oral communication. Listening and reading are combined according to actions and operations, which are based on the recognition of linguistic signs. Speaking and writing use the generative function of linguistic signs in actions and operations to create messages.

Types of speech activity can independently be included in one or another educational activity. So, reading is used to expand and deepen professional knowledge. The information extracted during reading can further stimulate non-speech and speech actions. 
The multifaceted goals and objectives, the difficulties of the content of training put the teacher and students in such conditions that do not allow achieving the required results without a deep understanding of the processes occurring in the human mind when mastering a foreign language.

Learning a foreign language as a means of communication involves mastering the processes of production and perception of a language in a non-native language. Methodological research and teaching experience show that it is much more difficult to develop speech skills than to acquire knowledge about language. But, there is a factor that allows to narrow the circle for which the above statement is not true.

A person at any age possesses approximately 100 billion neurons. There are approximately 300 trillion neural connections in the adult brain, and a quadrillion connections in the child's brain. A child is born with 100 billion connections, however, during the first 5 years of life, the child rapidly forms new connections, from 700 to 1000 connections per second. Each interaction of the child with the outside world as well as genetic information form new connections. Later, a kind of "natural selection" occurs: i.e. the connections that are addressed are reinforced and strengthened, and those that are passive are significantly weakened. Thus, we found out that each neuron has a connection with another neuron. What happens next? When you learn something, repeating impulses come from one neuron to another, they come again and again, and each next impulse passes the same path from a neuron to a neuron easier and faster than the previous one. In addition, our brain is constantly changing and forms new connections in the process of human mental activity. While learning foreign language a secondary sign system which is cornerstone new neuron connections is created. Due to the fact that the mastery of the second language takes place on the basis of the first, stereotypes of similar language elements are created by correcting existing nervous connections, and unfamiliar ones by creating new. Studying of each subsequent language leans on previous that leads to increasing the flexibility of organs of articulation and sensory corrections with each language and facilitates formation of neuron connections and reduces efforts on creation of stereotypes. The system of sign stereotypes of native and foreign languages has dynamic character as it has been constantly improving and increasing in size. While modification this system becomes more complicated due to formation of additional connections. For example, during introductory course of a foreign language, learners have been forming acoustical and motive images of sounds, words ad sentences. Later, the corresponding visual and handmotive images are added to them. Thus, the more you study, the better you get it. Dynamism of stereotypes depends also on individual features of the character and conditions of study: in the language environment or out of it. However, the variability of stereotypes does not prevent mutual understanding. The whole complex of images of a linguistic sign is inseparably linked with images of objects of the outside world and concepts corresponding to them. Thus, in my opinion, when choosing a methodology for a person who does not have experience in learning a foreign language, the key aspect is age.

Analyzing the process of foreign language learning of children aged from 3 to 5 years old, we came to conclusion that they perceive it as part of gaining general knowledge about the world around them but not as learning itself [8]. At this age, children still retained the skills of mastering their native language and easily transfer them to learning a second language. At this stage, the study of a foreign language coincides with the general flow of incoming information in the process of recognizing the world and is not considered as a single subject or science. For example, young learner perceives information that "apple" is "pomme" in French and "яблуко" in Ukrainian is quite natural, it is as obvious for them as the fact that apples can be red, yellow and green.

From 6 years the picture is changing. Acquiring general knowledge about the world gives way to a substantive study of the features, laws and phenomena of this world. However, children retain imaginative thinking, as primary in the development of new information material up to 8-9 years. This is the period when analytical thinking has not completely formed yet, and figurative thinking is still very active. That is why for students of this age category the most effective methodology is of teaching a foreign language is the one that is based on the activation of imaginative thinking of the learner, i.e. communicative. It is such tasks as communicative games, theatrical plays and projects that allow the child to develop being "in the language", and not analyzing it "outside" as it is when applying the techniques based on the cognitive component.

From 10 years old, knowledge acquired at an early age is formed into a certain system, a base on the basis of which teacher will have to form a structure of further knowledge about the language and the competences themselves. Scientists have found that the brain compares grammatical constructions of the new language with the corresponding grammatical constructions of the native language, and if the constructions are consistent, the brain makes a "substitution", i.e. uses the grammar of the native language when learning a foreign language. If, for example, the word order in the sentence is different, then the brain forms a new grammatical base [17]. But it is known that the construction of any structure will not take place without the application of the principle of consciousness. So, at this stage of teaching a foreign language, it will be advisable to change the methodology from a communicative to a structural one and this process will proceed quite harmoniously when teacher does it by applying sequentially an explicit approach first, and only then move on to an implicit one. 
Speaking about the change of methods, I do not mean the complete exclusion of the one and applying the other. It is known that no approach is used "in its pure" form. I just want to highlight the fact that up to 5 years old the only right one can be a communicative approach. This is perhaps the only period when only one method is used in training. Further, a differentiated approach is usually used in the teaching process.

Continuing the sequence proposed in this article, we will say that a method based on developments in the field of cognitive psychology and based on the principle of consciousness can be effectively used up to the age of 1516. The next change of approach is due to several factors. One of them is that the student is both psychologically and mentally ready to move on to the next level of learning a foreign language, where the communicative and structural approaches will be applied equally. At this level, the emphasis is usually focused not on the acquisition of new competencies, but on the development of existing ones, and that is why the principle of consciousness quickly becomes only an auxiliary one, and the improvement of communicative competencies becomes almost the only task. In addition, modern methodists believe that by this age adherence to the principle of consciousness helped to develop skills of independent work on language, which is a very important quality for the student because in today's world, when technology offers a wide range of self-study options, they have gained an incredibly important role. Most teenagers own a smartphone, laptop or tablet. This means that they have access to a large number of online learning opportunities. From a pedagogical point of view, online learning programs are the "first step" in directing students to self-study - they can themselves set learning goals and work to achieve the results at their own pace and at a level with which they feel comfortable [10].

So, we can say that this is where the first cycle of learning a foreign language closes. Depending on the tasks that the student will set for himself in the future, the methods for their achievement will be determined.

It should be noted that the above sequence of changes in methods and approaches in training is a review and is based on materials of general psychology of personal development in the process of growing up.

To build a sequence of application of methods and approaches in the formation of language competencies in a foreign language for an adult or young adult, we should see that the overall picture will be radically different. So by the age of 20, a person, regardless of psychological characteristics of his or her personality, has already formed principle of gaining the knowledge about the outward things through analysis and awareness of the information received. Nothing is taken "on faith", everything must be explained and proved. Thus, it becomes apparent that adults acquaintance with a foreign language occurs through the prism of awareness. Thus, it is clear that the teacher will combine two approaches - lexical and grammatical - which will give the most positive effect. Admittedly, this idea is not new. Much earlier, scientists have already described the effectiveness of this method. However, a very important thing, I would say a decisive one, is to create the most effective balance of the lexical and grammatical balance in the method. At the initial stage of learning a foreign language in adults, the formation of vocabulary causes a particular difficulty. Psychologically and mentally adults are ready to form structures and analyze grammatical constructions, but for obvious reasons, they are not ready for the communication process, the most effective way to expand the vocabulary. In this case, psyche of an adult creates an "inhibitory effect" that can be overcome only if there is a significant motivation. The stronger it is, the faster language competencies are developed. In any case, whatever the motive for learning a foreign language an adult has, a combination of structural and communicative approaches, with a predominance of the structural one, will give the best results.

Conclusions. All scientists involved in research work in the field observed in this article, believe the studies they conduct could potentially help people in great variety of life situations, especially in teaching and learning foreign languages. Each of the considered psychological theories has a rational grain, but offers interpretation of the phenomena (including language) only from any separate party. Different points of view on the understanding of the psychological features of language acquisition, and in particular the principle of consciousness, lead to the emergence of different teaching methods. Research in the field of linguistics, psychology, psycholinguistics and methods of teaching a foreign language outside the language environment and the development of intensive teaching methods have been and remain historically significant and traditional for domestic science. Cognitive psychology puts in the forefront the action of cognitive processes and while communicative focuses on the formation of speech skills. It can be argued that all theories include in their conceptual arsenal almost the full range of psychological phenomena. But each individual approach will inevitably be limited and one-sided, because language as a complex psychological, or rather psycholinguistic phenomenon combines all these psychological aspects, which are also interpenetrating and interdependent. This is true, the problem lies in the different arrangement of priorities and in what explanatory model each of these theories, according to the prevailing psychological concept, chooses for the interpretation of psychological phenomena.

\section{References:}

1. Арутюнова Н.Д. Язык и мир человека. М., 1998. 896 с.

2. Бехтерева Н.О. Механизмы работы мозга человека. Л.: Наука, 1988

3. Вундт В. Введение в психологию. СПб., 2002. 479 с. 
4. Выготский Л. С. Мышление и речь. М., 1999. 352 с.

5. Демьяненко М.Я., Лазаренко К. А., Мельник С.В. Основы общей методики обучения иностранным языкам. Киев, 1984. 254 с.

6. Засєкіна Л. В. Мовленнєві стилі у новій парадигмі психолінгвістичного знання / Л. В. Засєкіна // Психолінгвістика. 2012. Вип. 9. С. 48-55.

7. Засєкін С. В. Універсальні стратегії перекладу художнього тексту: досвід емпіричного психолінгвістичного дослідження. Ученье записки Таврического нац. ун-та им. В. И. Вернадского. Серия : Филология. Социальные коммуникации. Т. 24 (63). № 4. Ч. 2. Симферополь, 2011.

8. Колесникова И.Л., Долгина О.А. Англо-русский терминологический справочник по методике преподавания иностранных языков. СПб.: Русско-Балтийский информационный центр БЛИЦ, 2001. 224 с.

9. Райлянова В. Э. Особенности работы головного мозга у детей младшего школьного возраста в процессе формирования иноязычной речевой деятельности. Гуманитарный весник ГВУЗ «Переяслав-Хмельницкий государственный педагогический университет им. Г. Сковороды. 2019. С. 213-219.

10. Рубинштейн С.Л. Основы общей психологии. СПб., 1999. 781 с.

11. Фердинанд де Соссюр. Курс общей лингвистики. М., 1933. 432 с.

12. Alemi M., Sarab M., Lari Z. Successful learning of academic word list via MALL: Mobile assisted language learning. International Education Studies,. 5,6 2014. pp. 99-109.

13. Amichai-Hamburger J., Gazit T., Bar-Ilan J. et al. Psychological factors behind the lack of participation in online discussions. Computers in Human Behaviour,. 55 (A) 2016. pp 268-277.

14. Bostelmann, M., Lavenex, P., Lavenex, P. Children five - to-nine years old can use path integration to build a cognitive map without vision. Cognitive Psychology, 2020 https://doi.org/10.1016/j.cogpsych.2020.101307

15. Cowley-Cunningham, M. The Cognitive Perspective. Cognitive Psychology \& Cognitive Development: Theory and Practice. SSRN. 2017.

16. Kasumi, H..Communicative language teaching and its impact on students' performance. Journal of Educational and Social Research. Vol. 5 No.1 S1. 2015. http:/ 10.5901/jesr.2015.v5n1s1p155

17. Kirsten Weber, Morten H. Christiansen, Karl Magnus Petersson, Peter Indefrey, and Peter Hagoort. fMRI Syntactic and Lexical Repetition Effects Reveal the Initial Stages of Learning a New Language. Journal of Neuroscience. 2016 DOI: 10.1523/JNEUROSCI.3180-15.2016

18. Legare, C. Exploring explanation: Explaining inconsistent evidence informs exploratory, hypothesis-testing behavior in young children. Child Development, 83 (1) 2012, pp. 173-185, 10.1111/j.1467-8624.2011.01691.x

19. Meara, P., Miraplex, I. Tools for researching vocabulary. Multilingual Matters. 2016. 280 p.

20. Simon, J., Jaen, I. An overview of recent developments in cognitive literary studies // in book Cognitive literary studies: current themes and new directions/ University of Texas press. 2012. 